\title{
MUNICIPAL ENVIRONMENTAL MANAGEMENT: A PROPOSAL OF INSTRUMENTS FOR DIAGNOSIS OF PUBLIC ENVIRONMENTAL POLICIES IN THE METROPOLITAN AREA OF SALVADOR (MAS)
}

\author{
T. C. AZEVEDO ${ }^{1 *}$, A. A. PORTELLA ${ }^{1}$ and F I.M.G.SANCHEZ ${ }^{2}$ \\ ${ }^{1}$ Universidade Católica do Salvador (UCSAL) \\ ${ }^{2}$ Universidad de Salamanca (USAL) \\ tanaze@terra.com.br
}

Article submitted in February/2016 and accepted in February/2016

DOI: $10.15628 /$ holos.2016.3983

\section{ABSTRACT}

The aim in this paper is to propose a model for mapping strategies of municipal environmental management for local environmental public policies. To do so, the study adopted a theoretical approach. More specifically, there is discussion on the concepts of public policies and the scenario of the Brazilian municipal environmental management, a brief history of the aspects that involve current national environmental policies.
\end{abstract}

Methodologically, a bibliographical study was carried out through a literature review, which enabled the proposal of instruments for mapping actions and strategies of environmental management in the municipalities of the Metropolitan Area of Salvador (MAS). This theoretical study resulted in the creation of a model form that will be used by empirical researches for mapping the environmental public policies in the MAS City Halls.

KEYWORDS: Municipal environmental management; Public policies; Metropolitan Area of Salvador (MAS).

\section{GESTÃO AMBIENTAL MUNICIPAL: UMA PROPOSTA DE INSTRUMENTO PARA O DIAGNÓSTICO DE POLÍTICAS PÚBLICAS AMBIENTAIS NA REGIÃO METROPOLITANA DE SALVADOR (RMS).}

\section{RESUMO}

O presente artigo teve como objetivo apresentar uma proposta de modelo para mapeamento das estratégias de gestão ambiental municipal, com vistas a políticas públicas ambientais locais. Para tanto, o estudo respaldou-se em uma abordagem teórica. Como desdobramento, discutiu-se os conceitos de políticas públicas e o cenário da gestão ambiental municipal brasileira e breve histórico dos aspectos que envolvem a política nacional do meio ambiente nos dias atuais. Em relação à estratégia de pesquisa adotada, o trabalho apoiou-se em um estudo de natureza bibliográfica, por meio da revisão literatura, o qual apresentou uma proposta de instrumento para mapear as ações e as estratégias de gestão ambiental nos municípios integrantes da Região Metropolitana de Salvador (RMS). Este ensaio teórico foi encerrado com a concepção de um modelo delineado sob a forma de formulário, que será utilizado em pesquisa empírica para o mapeamento das políticas públicas ambientais em prefeituras da RMS.

PALAVRAS-CHAVE: Gestão Ambiental Municipal; Políticas Públicas; Região Metropolitana de Salvador (RMS). 


\section{INTRODUCTION}

The conciliation of economic development and nature preservation is a dilemma for governmental agents, companies and society in this century. This issue has been a priority in several forums, such as the UN Conference for Sustainable Development (Rio+20), held in 2012 and 2015, with the meeting of Heads of State and Government in commemoration of the UN $70^{\text {th }}$ anniversary, when the plan of action for 2030 was set up, with the establishment of seventeen global priority goals for sustainable development.

Thus, environmental issues have been included in the agenda of economic agents (companies, governments, civil society) due to the pressure over the years coming from the more and more emergent necessity of reordering the patterns adopted in the productive processes, especially concerning the use of natural resources. This scenario has stimulated global debates toward adoption of environmental practices and policies.

In this perspective, one may notice that the state agent can act as a promoter of sustainable development. According to Giaretta, Fernandes and Philppi (2012), debates on sustainable development and environmental management for cities are fundamentally important for paradigmatic change.

In this regard, local government becomes extremely important in the design of municipal environmental public policies. Consequently, mayors and other municipal political agents are indispensable in this process. This view is reiterated by Bursztyn and Nascimento's (2011) when they agree that municipal environmental management is structured by components and instruments and that it is a task of the local government (Executive and Legislative) to implement, design and evaluate environmental policies, also including society participation, in order to ensure environmental quality and life quality for citizens.

Thus, in this paper the aim is to propose a model for mapping strategies of municipal environmental management that contributes to local public policies in the cities which integrate the Metropolitan Area of Salvador (MAS).

Methodologically, this study was carried out through a bibliographical research, substantiating the writing of the literature review that supported the proposal of mapping actions/strategies of environmental management in the MAS municipalities. Besides, it included online searching for checking out the legislations on the subject and the MAS geographical data.

This study was elaborated from environmental debates related to the demands for specific and sectorial public policies. Then, we used the concepts, definitions and short history of the aspects that encompass the National Environmental Policy these days and the scenario of the Brazilian municipal environmental management. 


\section{THEORETICAL FRAMEWORK}

\subsection{Environmental issues and sustainability}

For many years modern society has used and consumed natural resources excessively, not usually paying attention to their limits, environmental risks and even nature ecological scarcity. In Brazil, this situation was reinforced by the model of development adopted in the 1950s, which prioritized national industrialization and had no concern with the social-environmental aspect. Another relevant point regards the significant population growth in urban areas over the latter decades, which resulted in people's agglomeration and consequent scarcity of environmental resources in the cities.

This view is reiterated by Giaretta, Fernandes and Philppi (2012, p. 527), who posit that environmental issues were perceptible from the 1960 s on, when the limitation of natural resources was evident and, in contrast, there was continuous population growth. From this, there was the initial inquiry of the development model adopted and the gap regarding socio-environmental sustainability.

On this subject, Freiria (2011) discussed the causes and implications of environmental crisis and stressed that they highlight political, economic, institutional, social and cultural dimensions and that their effects transcend national borders.

To support the discussion on environmental issues, Seiffert (2011, p. 07) said that environment and development are more and more linked to the international debate on the future of humanity since conservation, preservation and environmental quality have become a highly significant and current theme for citizens.

Thus, it is necessary to stress the importance of state agents' participation in the environmental discussion for they are some of the essential agents for organization and guidance of actions and policies of environmental management that can mitigate conflicts between the several interest groups. In this sense, Giaretta, Fernandes and Philppi (2012, p. 529) regard the discussions on sustainable development and environmental management for cities as constituents of a fundamental space for paradigmatic change, and suggest that environmental management in this municipalities should regard sustainability as a core pillar between society and environment in order to guide the models of development and formulation of public policies that can significantly impact on people's quality of life.

Regarding sustainability, it is important to highlight that the essential premises of this terminology are based on the frameworks of sustainable development. The document that contributed the most for popularization of this concept was disseminated in the 1980s. It is the Brundtland Report, named as "Our Common Future", written in 1987 by the "World Commission on Environment and Development' (WCED), which provided the following definition: sustainable development is "development that meets the needs of the present without compromising the ability of future generations to meet their own needs". According to Santos (2011, p. 08), this concept calls attention to the finitude of natural resources, social and economic issues of population. 
In fact, the perspective in the WCED document presupposes the adoption of postures and structural changes in lifestyle of society. On this issue, Sachs (1993) suggested that sustainable development should fundamentally be constituted by taking into account three core pillars: social equality, ecological prudence and economic efficiency; for improvement of human condition and respect for the ecosystem. Borja and Castells (1999, p. 195) also collaborated with this discussion by emphasizing the urban aspect of the subject and underlining that it is a strategy with varied dimensions integrated to city development and that it should consider, besides the environmental aspect, the increment of material wealth, life quality improvement, as well as social and cultural conditions.

Sachs's (2004, p. 15) view endorses the systematization of discussions on the subject, constituting the basic instrumental of sustainability, which, according to this theorist, comprises social, economic, ecological, geographical or spatial (territorial) and cultural dimensions in its design and conception. This approach reports the discussion of what he has defined as ecodevelopment and, thus, considering that the development planning should essentially encompass these dimensions.

Seiffert (2011, p. 05-39) introduced an improved version of Sachs's (1993; 2008) model by adding the technological dimension. Barbieri and Carvalho (2010, p. 84) posits that the most successful proposal in incorporating the concept of sustainable development was the one widespread by Elkington (2001), who introduced the model of management called Tipple Bottom Line (TBL), in which he proposed the generation of positive economic, social and environmental outcomes. Barbieri and Carvalho (2010, p. 85) affirmed that in the TBL model innovations must make positive contributions to the three dimensions of sustainability where they are applicable. Therefore, its premise enables benefits for all the actors integrated into the process organizations, society and environment. These theorists highlight that TBL is the most successful option in incorporating the concept of sustainable development since the three dimensions of sustainability enables innovations and positive contributions.

Thus, the perspective of Tipple Bottom Line (TBL) may also be incorporated into studies of government, especially the municipal one, so that its fundaments may contribute to public policies oriented to the issue of city sustainable development. This idea was endorsed by Cruz, Ferreira and Macedo's (2011) studies, who analyzed the index of sustainable development in municipalities of Rio de Janeiro State. Corroborating the approach of TBL, Moraes et al (2012) presented a proposal for municipal environmental planning and management toward sustainability.

Sachs's (1993, p. 37-38) proposal coupled with Borja and Castells's (1999, p. 193-203), Elkington's (2001) and Seiffert's (2011) ideas enabled elicitation of the six core pillars for development with sustainability that integrates environmental management of cities, where local government will be able to aggregate them into their policies and planning. Table 1 introduces these dimensions. 
Table 1 - Summary of sustainability dimensions

\begin{tabular}{|l|l|}
\hline Dimension & Approach \\
\hline Social & $\begin{array}{l}\text { Emphasis on social rupture related to threats and problems in several places. For } \\
\text { instance, equal income distribution, inclusion of several groups of society, } \\
\text { guarantee of dwelling and rights to work. }\end{array}$ \\
\hline Economic & $\begin{array}{l}\text { Management and efficient allocation of resources. Economic efficiency evaluated } \\
\text { at macrosocial levels. }\end{array}$ \\
\hline Environmental & $\begin{array}{l}\text { Emphasis on issues of ecosystem resources, how they are supplied and least } \\
\text { possible damage to life support; encouragement of renewable energy sources; } \\
\text { reduction in the volume of residues and pollutant emission; promotion of self- } \\
\text { limitation of consumerism; and establishment of norms appropriate to } \\
\text { environment protection. }\end{array}$ \\
\hline $\begin{array}{l}\text { Spatial } \\
\text { (territorial) }\end{array}$ & $\begin{array}{l}\text { Related to spatial distribution of resources, population and activities, oriented to } \\
\text { a more balanced rural-urban setting with better territorial distribution. }\end{array}$ \\
\hline $\begin{array}{l}\text { Cultural } \\
\text { historical } \\
\text { heritage }\end{array}$ & $\begin{array}{l}\text { Priority to aspects of endogenic grounds, local culture. Protection of local historical } \\
\text { heritage. }\end{array}$ \\
\hline $\begin{array}{l}\text { Technological or } \\
\text { innovational }\end{array}$ & $\begin{array}{l}\text { Priority to information, communication and creative economy in the construction } \\
\text { of intelligent cities. }\end{array}$ \\
\hline
\end{tabular}

Source: Sachs (1993, p. 37-38; 2004, p. 15), Borja and Castells (1999, p. 193-203), Elkington (2001) and Seiffert (2011), with authors' adaptation.

Table 1 displays the structural fundaments of the approach for development with sustainability. In order to achieve it, the six dimensions must work together. Regarding this discussion toward cities, incorporation and application of these principles are seen as relevant since the activities developed in urban areas, several times, make conditions inappropriate for inhabitants, contributing to a series of problems, such as those which involve the environment.

Based on all of this, development with sustainability in its environmental dimension is a fundamental element of relationships between several interest groups that will work in the definition and establishment of economic goals and the society they hope to achieve in the medium and long term.

\subsection{Fundaments of public policies and municipal environmental management}

Several theorists give definitions and views on the term Public Policy (PP), however, the approach in this study is based on Frey (2000), Souza (2006), Burgos (2008), Carvalho, et al (2010) and Freiria (2011).

According to Frey (2000), public policies are vulnerable to alterations as time passes; they are the outcome of a political process that mirrors an ample interest group. In Brazil, these studies are recent and their understanding emphasized the analysis of structures and institutions or the characterization of negotiation processes of specific sectorial public policies.

Souza (2006) posits that public policies have repercussions for economy and society and that it is a field which seeks both to "have the government act" and/or analyze actions and, whenever necessary, propose chances in the direction or course of these actions. His view is reiterated when he posits that:

"Public policies, after being designed and elaborated, develop into plans, programs, projects, database or information and research systems. When put into 
action, they are implemented and then submitted to follow-up and evaluation" (SOUZA, 2006, p. 26)

According to Burgos (2008, p. 144), public policies are regarded as a collective learning process for improving capability to tackle problems; they decisively influence the setting and legitimation of public agendas through a process of interlocution and democratic communication between society and government.

Carvalho, Barbosa and Soares (2010) assumed that public policies should have at least a flux of information concerning the aim to meet the demands of society. Thus, public government seeks to anticipate needs by planning and implementing actions that provide structural conditions for socioeconomic development of a country.

These views corroborate the understanding that public policies are actions institutionalized by the government for society in order to meet general and specific demands that come from collective needs. For instance, the issues concerning the use of natural resources.

To summarize the concept of PP, Souza $(2006$, p. 36$)$ introduced the following elements he regards as fundamental ones:

Enable the distinction between what the government intends to do and what they actually do;

Involve several actions and decision levels, although they are made concrete by governments, and not necessarily restrict themselves to formal participants since informal ones are also important;

Be openly inclusive and not limited to laws and rules;

Be an intentional action, with aims to achieve;

Although it has an impact in the short term, it is a long-term policy;

- Comprise processes subsequent to its decision and proposition, namely they also include implementation, execution and evaluation.

By emphasizing sectorial or specific policies, the discussion is focused on the aspect of environmental public policies, which according to Frey (2000):

“... it is unquestionable that the 'discovering' of environmental protection as a peculiar sectorial policy led to significant transformations of institutional arrangements in all dimensions of state actions. On the other hand, as a consequence of thematizing environmental issues, new political actors (environmental associations, institutes for environmental research, public departments in charge of environmental preservation) came into action and transformed and restructured the political process" (p. 27).

Thus, Freiria (2011, p. 13) stated that environmental public policies, in the current context of environmental crisis, have an important role due to the consequent possibilities of their function in defining paths and establishing criteria for human actions.

One can infer that perceptions of environmental public policies lead to the understanding that they have a dynamic nature and should comprise sectorial and specific issues, meeting the demands of a big interest group through outcomes. Thus, public entity is an actor of great relevance for addressing pressures from several interest groups for new conditions, revisions and 
even changes since municipalization of sectorial public policies, for instance, the environmental ones, may contribute to better identification of people's real needs due to its closeness to interest groups, conflicts, pressure and society as a whole.

Other studies reinforce the discussions that approach municipal environmental issues. Azeredo, Pasquis and Bursztyn (2007), for instance, highlighted the issue of State reform regarding the decentralization of environmental policies. Moura (2009) collaborated by provoking the discussion on the responsibilities of public entity related to difficulties and possibilities in the establishment of specific public policies.

Bursztyn and Nascimento (2011) published a paper on the contextualization and possible instruments of local management, its main structural axes and difficulties in implementing municipal environmental management. Giaretta, Fernandes and Philppi Jr. (2012, p. 530) contributed with discussions on public policies and municipal management for sustainable development and suggested that its establishment should be one of the priorities on the agenda of any state agent and that municipalities must guarantee the clauses of Articles 205 and 225 of Federal Constitution, that is, public policies which comprise the environmental dimension.

Based on this, it can be said that state agents, in this case municipal managers, as members of society, are the actors responsible for defining efficient actions of environmental management and its implementation so that adoption of environmental public policies may enable sustainable management of cities and, thus, the promotion of development with sustainability may be possible.

\subsection{Brief history of aspects that involve national environmental policy in Brazil}

Over time, Brazil has implemented legislations to guide Public Policies in relation to the environment in aspects of protection, exploitation and prevention, consequently, there was interlocution between PP and Law. According to Freiria (2011, p. 43), when related to environmental issues, their effectiveness is more and more subjected to the dialog with government.

In 1974, Brazil instituted the Plan of Development for Sectorial Control of Pollution (PDCSP, original initials in Portuguese) as a public policy oriented to environmental issues. In this document, the core axis was PP for territorial occupation and exploitation of natural resources, besides contributions to the relationship between man, territory and environmental issues since the aim was the promotion of men's easy access to land, improvement of labor conditions and promotion of the agroindustry in the North and Northeast regions (FREIRIA, 2011, p. 44). It was in this document that the control of industrial pollution caused by some activities was established. The PNDCS was revised and adapted over time for adjustment of issues on: the control of pollution caused by industrial activity; attempts to regulate territorial pollution; subdivision and dismemberment of urban territory; and establishment of guidelines for basic industrial zoning.

In 1981, with the Law 6.938, there was the promulgation of the National Environmental Policy (PNMA). This document was undoubtedly a milestone in broadening debates on environmental issues. It set the principles and concepts of environment and instituted the National Environmental System (SISNAMA). Through the PNMA, there was the structuration of several 
departments to carry out integrated actions toward the environment; instrumentalization of environmental managerial execution, supported by national legislations; establishment of shared and collective responsibility; and prediction of environmental damage recovery.

The PNMA was strengthened with the promulgation of the Constitution of 1988, which stated that the problem of environmental protection, an essential element for human being's life quality, is a mutual competence of federal entities, emphasizing the role of municipalities in addressing this matter. Then, Brazilian municipalities started to have a series of guidelines to follow, which were ruled by the Resolution 237/97 of the National Environmental Council (CONAMA).

Other recent actions from the Brazilian state entity to contribute to the guidelines of conservation, recovery and improvement of the environment deserve to be mentioned here, such as: Law 9.795/00, which instituted the National Policy of Environmental Education; Law 10.257/2001, referring to the Statute of Cities; National Policy on Climate Change (Law 12.187/2009); National Policy of Solid Residues (Law 12.305/2010); and National Policy of Urban Mobility (12.587/2012). These documents provide municipalities, as a territory in the production of political autonomy concerning the respect for environmental equilibrium and use of collective goods, with guidelines for establishment of policies faced with environmental issues, and production and dissemination of information to all of those involved in the process of environmental management.

The regulatory framework presented up to now aimed to emphasize the necessity of public entity, especially local government, to effectively work with instruments for prevention, control and detection of environmental impacts opportunely and proactively. Next section is dedicated to the discussion on some instruments suggested in the literature review. In addition, the model for mapping environmental public policies in the MAS municipalities is proposed.

\section{BRIEF OUTLINE OF THE MAS}

The Metropolitan Area of Salvador (MAS) was instituted in 1973 by the Complementary Law (CL) $14 / 73$, reordered by $C L 32 / 2008$ and aims to promote economic and institutional relationships between the cities which integrate it. This area comprises the following municipalities: Candeias, Dias d'Ávila, Itaparica, Lauro de Freitas, Madre de Deus, Mata de São João, Pojuca, Salvador, São Francisco do Conde, São Sebastião do Passé, Simões Filho and Vera Cruz.

The MAS, according to the Brazilian Institute of Geography and Statistics (IBGE), had $3,573,973$ inhabitants in 2010, the most populous in the Northeast. According to Silva (2014, p. 4), the MAS is in a prominent position nationally, it is the $8^{\text {th }}$ in population. Salvador, the capital of Bahia, had 2,675,656 inhabitants then and was the third most populous city in Brazil. Moreover, its commercial and service sector had a significant impact on local economy.

It is in this area that Camaçari Industrial Center is based. It is regarded as the largest industrial complex in South America and an important economic agent. According to Carvalho and 
Borges (2014, p. 82), at that time, there was a great transformation of regional productive structure, associated to national development policies.

Tourism growth was also noticed with the expansion of Mata de São João coast, where tourism stimulated proliferation of hotels. In Faria's (2013) view, the intensification of real estate speculation and the beginning of tourism in this region occurred due to the improvement in the road system and since then these activities have imposed themselves in the territory planning. Currently, this city has 5,756 rooms available in hotels, inns, hostels and chalets.

Thus, the MAS is a significantly important area for Bahia State in addressing the establishment of effective public policies that make it possible to optimize the relationship between development and sustainability. Silva's (2014, p. 33-46) studies provided evidences of expansion of this area through comparison of data collected by IBGE in 2010. On this subject, Table 2 displays the profile of territorial and population distribution, and total GDP.

Table 2 - Summary of demographic distribution of the MSA municipalities

\begin{tabular}{|l|l|l|l|l|}
\hline & \multirow{2}{*}{ Municipality } & Population & \multirow{2}{*}{ Area $\left.\mathbf{( k m}^{\mathbf{2}}\right)$} & $\begin{array}{l}\text { Total GDP } \\
(\mathbf{2 0 1 0}\end{array}$ \\
\cline { 3 - 4 } & & $\mathbf{( 2 0 1 0 )}$ & & $30,978,300$ \\
\hline 01 & Salvador & $2,675,656$ & 692,819 & $11,480,741$ \\
\hline 02 & Camaçari & 242,970 & 784,658 & $2,688,789$ \\
\hline 04 & Lauro de Freitas & 163,449 & 57,662 & $3,022,160$ \\
\hline 05 & Simões Filho & 118,047 & 201,223 & $2,565,905$ \\
\hline 06 & Candeias & 83,158 & 258,357 & $1,924,474$ \\
\hline 07 & Dias D'Ávila & 66,440 & 184,230 & 368,307 \\
\hline 08 & São Sebastião do Passé & 42,153 & 538,324 & 302,566 \\
\hline 09 & Mata de São João & 40,183 & 633,198 & 229,682 \\
\hline 10 & Vera Cruz & 37,567 & 299,734 & $8,547,192$ \\
\hline 11 & São Francisco do Conde & 33,183 & 262,856 & 855,780 \\
\hline 12 & Pojuca & 33,066 & 290,117 & 107,324 \\
\hline 13 & Itaparica & 20,725 & 118,040 & 260,182 \\
\hline & Madre de Deus & 17,376 & 32,201 & $\mathbf{6 3 , 3 3 1 , 3 6 3}$ \\
\hline
\end{tabular}

Source: Silva (2014) and IBGE (2015), adapted by us.

$(*)$ in thousands of real and without taxes

As one can see in Table 2, Salvador has the largest population, with $75 \%$ of total inhabitants of the MAS. Regarding the Gross Domestic Product (GDP), this city had largest amount in 2010; however, its territory is not the largest one, coming in second place. Camaçari is larger than Salvador regarding territorial extension in $\mathrm{Km}^{2}$ and its population sum up $7 \%$ of total inhabitants of the MAS. A similar situation occurs with the other municipalities in the comparison between population and area. It is important to stress that São Francisco do Conde, even holding the $10^{\text {th }}$ position in number of inhabitants, has total GDP in third place amongst the MAS cities. Accordingly, it is evident that the capital of Bahia has a population of great impact the other municipalities of the MAS. 
As a visual aid of the geographical localization of the cities which are part of the MAS, its map follows below:

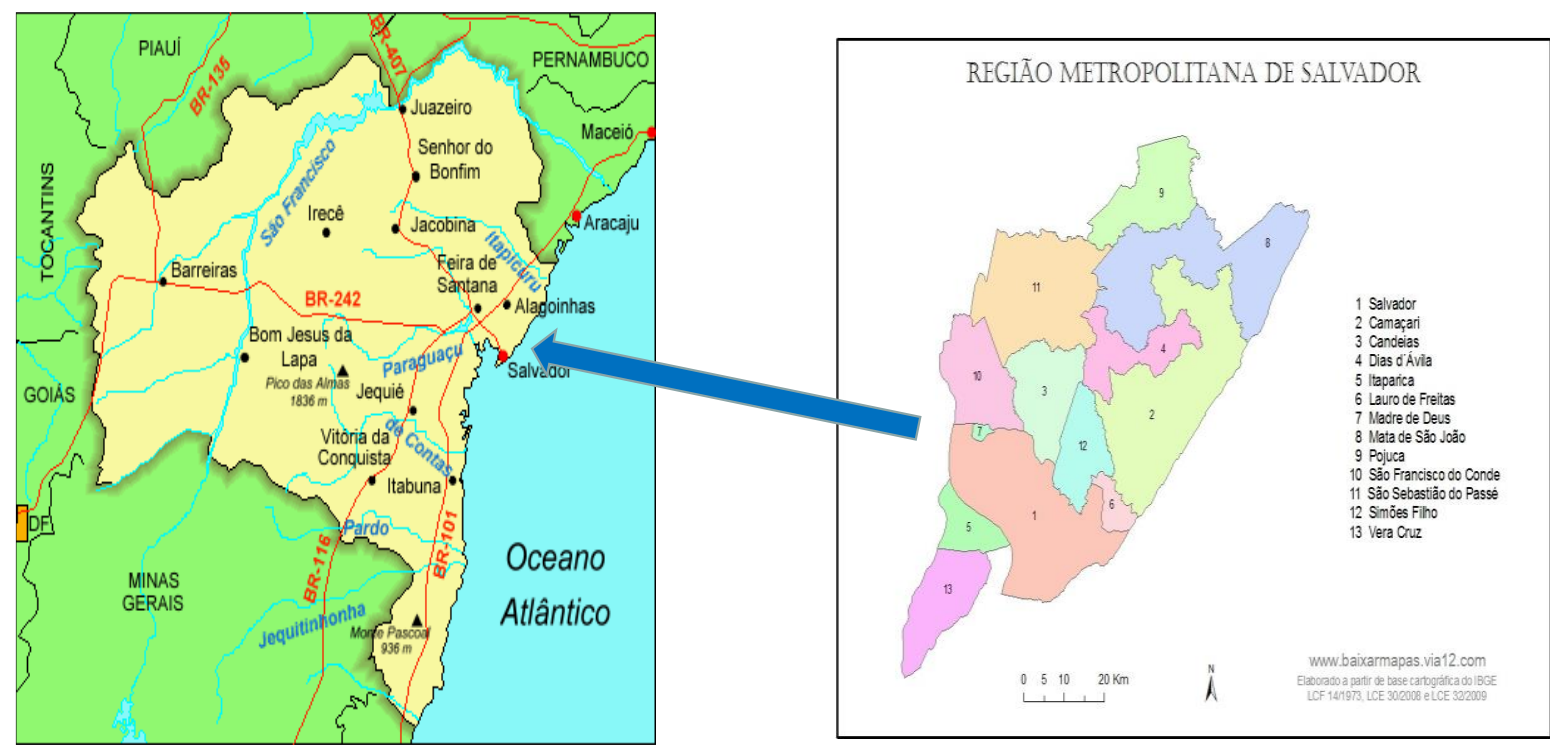

Source: adapted from Só Geografia, www.sogeografia.com.br and baixar mapas geográficos.

http://www.baixarmapas.com.br/mapa-da-regiao-metropolitana-de-salvador/, access on 15 Feb 2016.

The map above displays the outline of the cities which are part of the MAS. Besides, it is important to mention that it has a very long coast, from Salvador to Lauro de Freitas, Camaçari through and Mata de São João.

Therefore, the arguments presented confirms the interest in enlarging the number of studies on the environmental matter and its consequences for MAS through the creation of an instrument which makes it possible to diagnose PP in the municipalities of this area and, thus, identify the environmental actions and strategies adopted/implemented in these localities.

\section{INSTRUMENTS FOR MAPPING ACTIONS AND STRATEGIES OF MUNICIPAL ENVIRONMENTAL MANAGEMENT}

The discussion of possible relevant instruments for mapping action and strategies of municipal environmental management fulfills the initial aim of understanding the importance of decentralization of actions that involve environmental issues, shared amongst spheres of power.

On this theme, Azevedo, Pasquis and Bursztyn (2007) noticed that decentralization involves the transference of authority and respective legal and administrative competences to another government power, either in state or municipal spheres. This process made some environmental policies possible.

In Brazil, decentralization advances regarding public policies are evident, such as environmental permitting, which is mandatory in the whole country since 1983 after being instituted by federal Law 6.938/81 (National Environmental Policy). This context provided municipalities with ampler regulation power, since environmental permitting of activities related to local government became its own competence. 
Bursztyn and Nascimento (2011) state that decentralization has occurred and has been established as a trend to increase year after year, and it seems to be irreversible as one can check it out on data by IBGE (MUNIC), which display an increasing number of municipalities that are structuring themselves toward environmental management. These theorists suggest instruments of municipal environmental management, such as: master plan; building code; land law; land subdivision law; urban code of conduct; environmental zoning; city statute; environmental permitting; location permit and business license for activities; Agenda 21; environmental education; and so on.

Brazilian municipalities can use other instruments for the establishment of environmental public policies. In Giaretta, Fernandes and Philppi Jr.'s (2012, p. 530) view, they are divided into: legal (organic law, master plan, land use and occupation, and environmental code); economic (municipal fund for environment, tax incentives, municipal consortia); administrative (specific unit for this issue, technical capacity of human resources, partnership with other private institutions, universities and related entities); and institutional (environmental education, Agenda 21, environmental councils and environmental information systems).

Moraes et al (2012), anchored on the three pillars of sustainability, proposed an instrument of municipal environmental planning for tourism. This proposal was based on the conceptions of the Tipple Bottom Line (TBL). This model was designed to subsidize orientation of economic development together with environmental protection and municipal social inclusion.

Dias and Matos (2012, p. 202-203) suggested that the proposal of environmental public policies should be based on ample analysis of local resources potentialities, peculiar features, complexity of environmental issues, integration of several strata of society and adoption of instruments capable of addressing environmental preservation, conservation and recovery.

Thus, the ideas by Frey (2000), Souza (2006), Burgos (2008), Carvalho, Barbosa and Soaresl (2010), Freiria (2011), Azevedo, Pasquis and Bursztyn (2007), Bursztyn and Nascimento (2011), Giaretta, Fernandes and Philppi Jr. (2012), Moraes et al (2012) and Dias and Matos (2012) provided a strong methodological basis for the construction of an instrument for future investigation. Thus, the model, which is introduced in section 5.2, is an instrument intended to contribute for the diagnosis of the municipality structure, the actions taken and implemented for local environmental management, extent of the environmental regulation of the municipalities involved and how local government behaves regarding the relationship and communication between the environment department and its different interest groups.

\subsection{Methodology}

In order to design the instrument for mapping the environmental actions and strategies adopted by the municipalities of the MAS, the literature review was the basis for the conception of this study. To do so, we used books, papers on public policies and municipal environmental management, and instruments and models to measure actions and strategies adopted by City Halls. We also uselikertd legislations related to the theme to subsidize the discussion on progressive and historical aspects of national environmental policy.

The proposal for mapping actions and strategies of municipal environmental management included inquiries regarding the adoption/implementation of environmental public policies to be 
applied to the City Halls that integrate the Metropolitan Area of Salvador (MAS). For designing this model, besides the specific literature review, we adopted scientific methodological fundaments to subsidize the form design, which enabled its analysis and measurement of results on Likert scaling. This investigation instrument, according to Vieira and Dalmoro (2008), is used as a way to measure the realness of the study subject. In order to do so, the authors claim that the scale construction has had variations in its frame since its creation, but that study showed that the five-level scale suited better.

The decision of creating an inquiry instrument based on Likert was made for its appropriateness to social research. For Martins and Theóphilo (2009, p. 96), this strategy of research comprises a series of items introduced as statements, which are judged by people, who choose one out of five or seven options on scale. They also comment on its high use in social investigations. Thus, Likert scale seeks to quantify interviewees' opinions and attitudes in a certain study. From Vieira and Dalmoro's (2008) study, we decided to design a model which seeks to cover five levels of application of environmental public policy strategies in the cities of the Metropolitan Area of Salvador (MAS).

Concerning the importance of effective environmental planning which may contribute to sustainable development in the municipalities of the MAS, this paper initially presents the designing of a model for mapping strategies of environmental public policies of the cities under study. The design of this proposal was carried out through the reading and understanding of the studies referred to throughout this paper.

Initially, the proposal encompasses four axes in its conception according to the following aspects:

1) Formal structure of the City Hall in the environmental area - this item aims to check how the municipality organized itself, that is, whether it created or not specific spaces of action for issues related to the environment;

2) Environmental measures adopted/implemented by the municipality - this phase is dedicated to the measurement of aspects related to training municipal personnel, program of environmental education, adoption of an environmental management system, creation of municipal fund, budget planning, creation of consortia and instruments of environmental control;

3) Local environmental legislations - norms of environmental education, environmental technical norms, specific taxation, municipal environmental code;

4) Relationship and communication of the environment authority - intra and intercommunication with actors and interest groups.

Framed on Likert scaling, this instrument, which will be applied to the City Halls of the MAS, was designed taking into account five levels of this scale, as it is displayed below:

1) - fully apply or follow the statement;

2) - apply the statement partially;

3) - little evidence of application of the statement;

4) - the municipality is indifferent to or not aware of the statement;

5) - the municipality do not apply the statement 
This instrument, which is introduced in the next section, will be answered by managers of environment departments of the City Halls of the MAS. Optionally, administrative employees of these departments may participate in this future investigation. They will receive the form through e-mail in order to provide their answers and send it back through e-mail as well. There is the possibility of conventional mail delivery or even in-hand delivery, depending on the local manager availability.

\subsection{Proposed model of investigation - analysis and discussion}

Framed as a form, this instrument of diagnosis of environmental public policies in the Metropolitan Area of Salvador (MAS) is mainly based on the conceptual premise of adoption of environmental public policies and whether there is evidence of development with sustainability in the municipality.

Below, Table 3 displays the model form for checking the actions, strategies and practices of environmental management in the municipalities of the MAS.

Table 3 - Form for mapping instruments and strategies of environmental public policies in the Metropolitan Area of Salvador (MAS)

\begin{tabular}{|c|c|c|c|c|c|}
\hline ESTRATEGY ADOPTED/IMPLEMENTED & PREI & EREN & CALE & & \\
\hline I - Formal structure of the City Hall for environment & 01 & 02 & 03 & 04 & 05 \\
\hline $\begin{array}{l}\text { Municipal Environment Secretariat as a structure linked to } \\
\text { local executive government }\end{array}$ & & & & & \\
\hline Environment Secretariat linked to other secretariats & & & & & \\
\hline $\begin{array}{l}\text { Environment department associated with another } \\
\text { administrative department }\end{array}$ & & & & & \\
\hline Active participation of the environment council & & & & & \\
\hline Functionality of the environment council & & & & & \\
\hline Inquiry out of the scale & & & & & \\
\hline $\begin{array}{l}\text { Department responsible for municipal environmental } \\
\text { management }\end{array}$ & & & & & \\
\hline Lifetime of the municipal environment department & & & & & \\
\hline $\begin{array}{l}\text { II - Environmental measures adopted/implemented by the } \\
\text { municipality }\end{array}$ & 01 & 02 & 03 & 04 & 05 \\
\hline $\begin{array}{l}\text { Specific technical training of administrative personnel of the } \\
\text { environment department }\end{array}$ & & & & & \\
\hline Programs of environmental education in municipal schools & & & & & \\
\hline Creation of Municipal Environmental Fund & & & & & \\
\hline $\begin{array}{l}\text { Integrated system of environmental information with several } \\
\text { interest groups }\end{array}$ & & & & & \\
\hline Creation of inter-municipal consortia & & & & & \\
\hline $\begin{array}{l}\text { Budget of the municipality for implementation of municipal } \\
\text { environmental public policies }\end{array}$ & & & & & \\
\hline $\begin{array}{l}\text { Municipal environmental management comprises: municipal } \\
\text { planning, environmental zoning, evaluation of studies on } \\
\text { environmental impact, inspection and control. }\end{array}$ & & & & & \\
\hline Adoption of a system for selective collecting of residues & & & & & \\
\hline Adoption of local afforestation planning & & & & & \\
\hline Adoption of measures and actions of water reuse & & & & & \\
\hline Measures and actions of energetic efficiency & & & & & \\
\hline Adoption of a system for sustainable public purchase & & & & & \\
\hline III - Local environmental legislations & & & & & \\
\hline
\end{tabular}




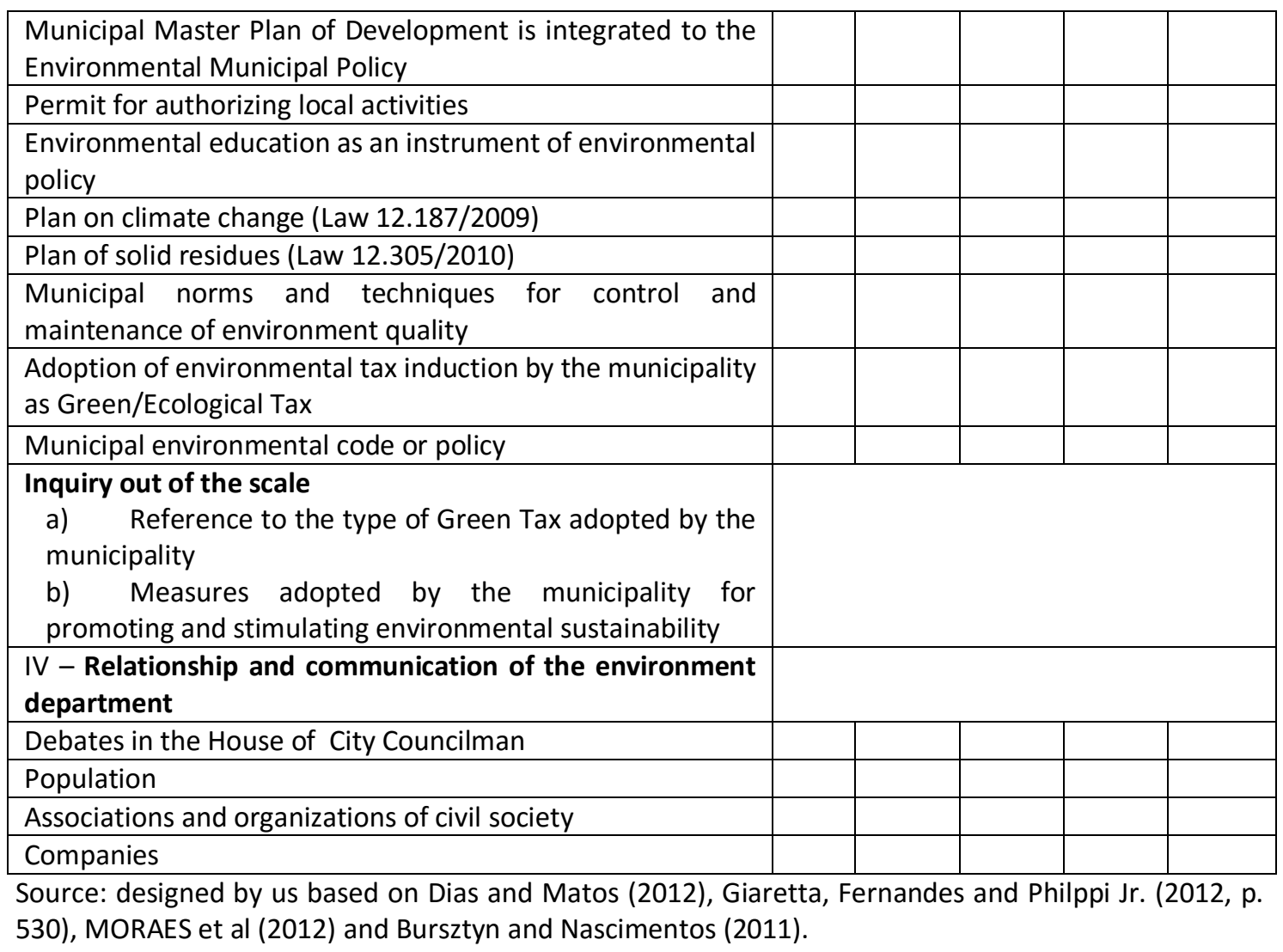

Table 3 displays the essential elements for investigating the municipalities of the MAS. This investigation will provide awareness of local management reality regarding the adoption of environmental public policies. Thus, this document will enable future investigations about one individual diagnosed municipality or even about the establishment of comparative patterns.

\section{CONCLUSION}

This study promoted debate about sustainability and public policies in a perspective that it is truly important, especially when related to specific issues such as municipal environmental management. It was clear that municipal government stands out in this context since it works closer to local demands and, thus, has the possibility of interacting through more effective and consistent PP. Therefore, we understand that mayors are closer to demands and requirements of civil society concerning environmental issues.

Thus, the ideas formulated here through in-depth literature review and legal definitions, established by specific legislations, made it possible to propose an instrument for gauging the adoption/implementation of environmental public policies in the municipalities of the MAS, which was based on four central axes of investigation: knowledge of City Halls' formal structure on environment issues; measures adopted/implemented in municipal environmental management; evidence of environmental legislations; and relationship and communication with environment authorities. Ergo, with the creation of the form, the main aim of this study was achieved.

The second stage of this study is the empirical inquiry for mapping the environmental public policies adopted and, thus, make a diagnosis of the cities which integrate the MAS and check whether the actions and practices adopted enabled development with sustainability. 
Other studies should be carried out for expanding the discussion. Some possibilities for future studies are: measurement of natural capital by municipal public entities; municipal costs for discharging residues produced by companies and people; and adoption of sustainable practices for solving problems of landfills at competitive prices.

\section{ACKNOWLEDGMENTS}

This study has been supported by the Coordination for Improvement of Higher Education Personnel (CAPES, original initials in Portuguese) - Brazil - Institutional Program of Sandwich Doctorate Abroad - PDSE.

\section{REFERENCES:}

1. AZEVEDO, A.; PASQUIS, R.; BURSZTYN. A reforma do estado, a emergência da descentralização e as políticas ambientais. Revista do Serviço Público, 58 (1): 37-55, Jan/Mar, Brasília, 2007.

2. BAIXAR MAPAS GEOGRÁFICOS. Mapa da Região Metropolitana de Salvador. http://www.baixarmapas.com.br/mapa-da-regiao-metropolitana-de-salvador/, access on 15 Feb 2016.

3. BARBIERI, J. C.; CARVALHO, A. P. Innovation for Sustainability: Overcoming the Productivity of the Sugar-and-Ethanol Industry's Conventional System. Journal of Technology Mankagement \& Innovtion. Vol.05, n. 04. 2010.

4. BINSZTOK, J. Principais vertentes (escolas) da (des) ordem ambiental. In: SANTOS, M.; BECKER, B. (orgs.). Territórios, territórios ensaios sobre o ordenamento territorial. 3rd edition. Lamparina, 2007.

5. BORJA, J.; CASTELLS, M. Local y Global: La gestión de las ciudades en la era de la información. Santatillana ediciones, Madrid: 1999.

6. BRUNDTLAND, Gro Harlem, and World Commission on Environment and Development. Our Common Future: Report of the World Commission on Environment and Development. Oxford: Oxford University Press, 1987.

7. BUARQUE, S. C. Metodologia de planejamento do desenvolvimento local e municipal sustentável. Brasília: INCRA/IICA, 1999BRASIL. Constituição (1988). Constituição da república federativa do Brasil de 1988. Available on: http://www.planalto.gov. br/ccivil_03/Constituicao/Constituicao.htm. Access on 22 May 2013.

8. . Resolução $n^{\circ} 237$ do Conselho Nacional do Meio Ambiente, de 19 de dezembro de 1997. Estabelece critérios para o licenciamento ambiental pelo município. Diário Oficial da República Federativa do Brasil, Poder Executivo, Brasília, DF, 20 dez. 1997.

9. Estatuto da cidade. Lei no 9.795, de 27 de abril de 1999. Available on: <http://www.planalto.gov.br/ccivil_03/Leis/L9795.htm>. Access on 12 July 2013.

10. BURSZTYN, M. A. A.; NASCIMENTO, D. T. Descentralização da gestão ambiental: análise do processo de criação de organizações municipais de meio ambiente no sul catarinense. Revista do Serviço Público Brasília, 62 (2): 185-208 Abr/Jun 2011. 
11. BURGOS, G. Q. Políticas públicas y medio ambiente. Tecnologia en Marcha, vol. 21-1, eneromarzo, p. 141-151, Costa Rica, 2008.

12. CARVALHO, M. L; BARBOSA, T. R. C. G; SOARES, B. J. A Implementação de política pública: uma abordagem teórica e crítica. In: $X$ Colóquio Internacional sobre Gestión Univesritaria en América del Sur. Mar del Plata.2010.

13. CARVALHO, I. M.; BORGES, A. M. C. A Região Metropolitana de Salvador na rede urbana brasileira e sua configuração interna. In: CARVALHO, I. M. M.; PEREIRA, G. C. (Orgs). Como anda Salvador: transformações na ordem urbana. Rio de Janeiro: Letra Capital: Observatório das Metrópoles, 2014 p.77-108.

14. CRUZ, C. F.; FERREIRA, A. C. S.; MACEDO, M. A. S. Índice de desenvolvimento sustentável: uma análise apoiada em DEA para os municípios do estado do Rio de Janeiro. Revista Gestão \& Regionalidade, vol. 27, n. 81, set/dez. 2011.

15. DIAS, Reinaldo; MATOS, Fernanda. Políticas públicas: princípios, propósitos e processos. São Paulo: Atlas, p. 1-264, 2012.

16. ELKINGTON, John. The triple bottom line for 21st century business. The Earthscan reader in business and sustainable development, p. 20-43, 2001.

17. FARIA, G. A. Natureza, apropriação e resistência: contradições na dinâmica de ocupação territorial da zona litorânea de Mata de São João - Bahia. Dissertação de mestrado. Mestrado em Planejamento Territorial e Desenvolvimento Social. 2013.

18. FREY, K. Políticas públicas: um debate conceitual e reflexões à prática da análise de políticas públicas no Brasil. (Planejamento e políticas públicas. N. 21 2000).

19. FREIRIA, R. C. Direito, gestão e políticas públicas ambientais. São Paulo: Senac São Paulo, 2011.

20. GIARETTA, J. B. Z.; FERNANDES, V.; PHILLIPPI JR. A. Desafios e condicionantes da participação social na gestão ambiental municipal no Brasil. Revista Organização $e$ Sociedade (O\&S), v.19 - n. 62, p. 527-548 - Julho/Setembro. Salvador,2012.

21. IBGE, Instituto Brasileiro de Geografia e Estatística. Available on: http://www.cidades .ibge.gov.br/xtras/uf.php?lang=\&coduf=29\&search=bahia. Access on 10 Oct 2013, 06 Jun 2014 and 15 Oct 2015.

22. MORAES, C. S. B. et al. Planejamento e gestão ambiental municipal: uma proposta metodológica visando a sustentabilidade. Holos Enviroment. VI. 12 n. 1, -. 12-26, 2012.

23. MARTINS, G. A.; THEÓPHILO, C. R. Metodologia da investigação científica para ciências sociais aplicadas. 2a ed. São Paulo: Atlas, 2009.

24. MOURA, A. S. (Org.). Políticas públicas e meio ambiente: da economia política às ações setoriais. Recife: Fundação Joaquim Nabuco, Editora Massangana, 2009.

25. SACHS, I. Estratégias de transição para o século XXI. In: BURSZTYN, M. (Org.). Para pensar o desenvolvimento sustentável. São Paulo: Brasiliense, 1993.

26. . Desenvolvimento: includente, sustentável, sustentado. Rio de Janeiro: Garamond, 2008

27. SANTOS, N. N. P. Cidade e sustentabilidade territorial. Mercator, Fortaleza, v. 10. N.23, p. 07-22, set/dez. 2011 
28. SEIFFERT, M. E. B. Gestão Ambiental: instrumentos, esfera de ação e educação ambiental. 2a ed. São Paulo: Atlas, 2011.

29. SILVA, S. B. M.; SILVA, B. N.; SILVA, M. P. A Região Metropolitana de Salvador na rede urbana brasileira e sua configuração interna. In: CARVALHO, I. M. M.;

30. SÓ GEOGRAFIA. Mapa do estado da Bahia http://www.sogeografia.com.br/Conteudos/ Estados/Bahia/. access on 15 Feb 2016

31. PEREIRA, G. C. (Orgs). Como anda Salvador: transformações na ordem urbana. Rio de Janeiro: Letra Capital: Observatório das Metrópoles, 2014.

32. SOUZA, C. Políticas Públicas: uma revisão de literatura. Revista Sociologias, ano 8 n. 16 jul/dez. 2006. 